FACULTY OF ECONOMICS AND APPLIED ECONOMIC SCIENCES

CENTER FOR ECONOMIC STUDIES

ENERGY, TRANSPORT \& ENVIRONMENT

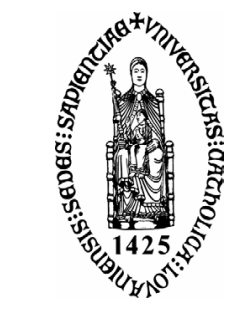

KATHOLIEKE UNIVERSITEIT LEUVEN

WORKING PAPER SERIES

$n^{\circ}$ 2004-12

\title{
Vertical and horizontal tax competition in the transport sector
}

\section{B. De Borger (Department of Economics, University of Antwerp)}

S. Proost (K.U.Leuven - CES; CORE - UCLouvain)

September 2004

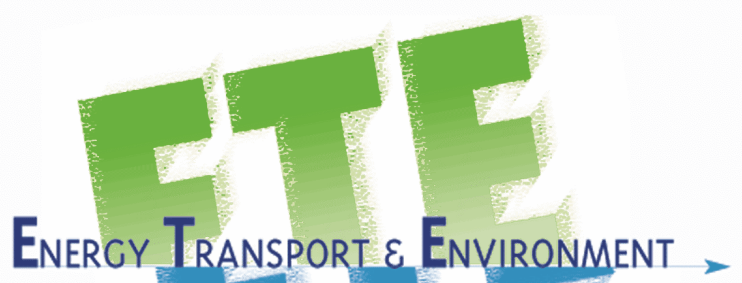

secretariat:

Isabelle Benoit

KULeuven-CES

Naamsestraat 69, B-3000 Leuven (Belgium)
tel:
+32 (0) 1632.66 .33
fax: $\quad+32(0) 1632.69 .10$

e-mail: Isabelle.Benoit@econ.kuleuven.ac.be http://www.kuleuven.be/ete 


\title{
Vertical and horizontal tax competition in the transport sector (*)
}

\author{
Bruno De Borger \\ Stef Proost
}

\begin{abstract}
The purpose of this paper is to review the literature dealing with horizontal and vertical tax competition in the transport sector, taking into account the role of transport externalities. Our emphasis throughout is on tax competition between governments, not between private suppliers. For the various different settings (horizontal and vertical competition, parallel and serial networks), we discuss the relevance of tax competition and describe the type of results typically obtained. We further point out the relevance of different types of tax competition for transport policy in a European setting. Finally, we discuss the losses of non-cooperative behaviour of governments.
\end{abstract}

JEL codes: R48,H71,H21

(*) Bruno De Borger: Department of Economics, University of Antwerp; Stef Proost: Center for Economic Studies, Catholic University Leuven and CORE, LLN,Belgium. A previous version of this paper was presented at the STELLA-conference in Athens, Greece, April 2004. We acknowledge support of the EC research consortia MC-ICAM and REVENUE and benefited from useful comments by the participants of the STELLA seminar in Athens, June 2004 and more in particular the comments of P. McCarthy. 


\section{Introduction}

The purpose of this paper is to review the fairly limited literature on tax competition in the transport sector, and to discuss its relevance for policy making in a European setting. To be more precise, we focus on two types of tax competition, resulting from different relationships between governments. First, vertical tax relations between governments exist when one government (e.g., the "federal" level) rules over a territory that consists of several states or regions that each have their own government. The interactions between these different levels of government imply the potential for vertical tax competition. Second, horizontal tax competition results when governments at the same level compete; consider, for example, competition between regions or states in a federal country, or competition between countries within the EU.

Note that our survey is restricted on at least three accounts. One is that we limit the discussion to competition between two types of government. Obviously, in principle different types of agents can compete for tax or toll revenues: governments, public companies (e.g., railways) or private companies (e.g., private bus companies, private road authorities). This paper restricts the analysis to the competition between governments for two reasons. First, the competition between private suppliers has already been analyzed and surveyed in more detail in the literature (see, e.g., de Palma, A. and R. Lindsey (2000)). Second, although private companies sometimes operate the transport services or the required infrastructures, governments ultimately regulate and control the pricing and tax policies that are used.

A second restriction is that we mainly focus on competition in terms of taxes and pricing instruments. Of course, other instruments in the competition for transport tax or toll revenues could be studied as well. Investment in capacity and in quality (road surface, ancillary services) can indeed also be used to attract traffic: this results in 'expenditure competition'. In this paper, however, we mainly emphasize the use of pricing instruments: taxes, tolls, fares, user charges, etc. We are interested in the effect of tax competition on the level of the pricing instruments, on total transport flows, and on the revenues ultimately received by the different governments.

The behaviour of governments is not easy to characterize: it is the result of a complicated game between voters, politicians, bureaucrats and policy makers. A third restriction of our survey is that, in most of the literature reviewed in this paper, it is assumed that the government maximizes some weighted sum of the welfare of its 
voters: the authorities are assumed to be interested in the consumer surplus of the local transport users and in all transport tax revenues it collects. This assumption is in line with the mainstream political economy literature (see Dixit et al., 1997) and allows us to make welfare judgments on the outcome of policies.

Structure of the paper is as follows. In Section 2, we first provide a quick overview of the various types of tax and expenditure externalities related to the transport sector. Section 3 then focuses on horizontal tax competition in transportation. Since issues of horizontal tax competition have a long tradition in public economics, it will be instructive to first briefly review what the public finance literature has to say on this type of tax competition, and then to focus in detail on applications in transportation. The emphasis will be consecutively on parallel and serial tax competition. The scarce literature on vertical transport tax competition is treated in Section 4. Finally, a concluding section points at a number of important topics for further research.

\section{$\underline{\text { 2. Fiscal externalities in transportation: a quick overview }}$}

Transport pricing with multiple governments and externalities is complicated because many vertical and horizontal fiscal externalities occur simultaneously with spill-overs of congestion and environmental externalities. That foreign traffic creates congestion externalities, noise, accidents and air pollution on the home territory is well known (see De Borger and Proost (2001)). What is less well known is that the tax and expenditure instruments that countries use to correct these externalities by themselves create a series of problems. Indeed, they lead to fiscal externalities whenever the pricing or expenditure policy of one government affects the objective function of other governments without proper compensation.

Table 1 makes abstraction of pollution and congestion and lists some of the fiscal and expenditure externalities in transportation. Both horizontal and vertical tax and expenditure externalities are considered. Moreover, the table further distinguishes direct versus indirect externalities. Direct fiscal externalities directly affect prices or local public good provisions for non-residents, whereas indirect externalities in addition affect tax revenues of other governments. 
As previously argued, in this paper we will mainly focus on tax externalities. Note that the relative importance of tax competition and tax exporting itself will strongly depend on the mobility of the tax base, and therefore on the specific tax instruments used. For example, if fuel taxes are used as one of the main instruments, tax competition may largely dominate tax exporting (especially in small open economies), whereas the latter may become much more relevant if road tolls are used in large countries.

Table 1: fiscal and expenditure competition in transportation

\begin{tabular}{|c|c|c|c|}
\hline Type & Source & Transport example & $\begin{array}{l}\text { Potential } \\
\text { implications }\end{array}$ \\
\hline $\begin{array}{l}\text { Direct horizontal } \\
\text { fiscal externality }\end{array}$ & $\begin{array}{l}\text { Tax exporting: } \\
\text { desire of } \\
\text { governments to } \\
\text { shift the tax burden } \\
\text { to foreigners }\end{array}$ & $\begin{array}{l}\text { High taxes on } \\
\text { services or on parts } \\
\text { of the infrastructure } \\
\text { used intensively by } \\
\text { foreigners }\end{array}$ & $\begin{array}{l}\text { Too much reliance } \\
\text { on taxes borne by } \\
\text { foreigners }\end{array}$ \\
\hline $\begin{array}{l}\text { Indirect horizontal } \\
\text { fiscal externality }\end{array}$ & $\begin{array}{l}\text { Tax competition } \\
\text { for a mobile tax } \\
\text { base }\end{array}$ & $\begin{array}{l}\text { Low taxes on fuel } \\
\text { to generate extra } \\
\text { revenues in small } \\
\text { open economies } \\
\text { (e.g., Luxemburg) }\end{array}$ & $\begin{array}{l}\text { Downward } \\
\text { pressure on tax } \\
\text { rates }\end{array}$ \\
\hline $\begin{array}{l}\text { Indirect } \quad \text { Vertical } \\
\text { fiscal externality }\end{array}$ & $\begin{array}{lr}\text { Overlapping } & \text { tax } \\
\text { bases: potential for } \\
\text { higher and lower } \\
\text { government to } \\
\text { partially tax the } \\
\text { same base }\end{array}$ & $\begin{array}{l}\text { Federal and } \\
\text { regional fuel taxes }\end{array}$ & $\begin{array}{l}\text { Excessive taxes on } \\
\text { the shared tax base }\end{array}$ \\
\hline $\begin{array}{l}\text { Direct horizontal } \\
\text { expenditure } \\
\text { externality }\end{array}$ & Benefit spillover & $\begin{array}{l}\text { Infrastructure } \\
\text { investment }\end{array}$ & $\begin{array}{l}\text { Under provision of } \\
\text { such activities }\end{array}$ \\
\hline $\begin{array}{l}\text { Indirect horizontal } \\
\text { expenditure } \\
\text { externality }\end{array}$ & $\begin{array}{l}\text { Expenditure } \\
\text { competition }\end{array}$ & $\begin{array}{lr}\text { Infrastructure } \\
\text { investment } \\
\text { attract to } \\
\text { business }\end{array}$ & $\begin{array}{l}\text { Overprovision } \\
\text { such activities }\end{array}$ \\
\hline $\begin{array}{l}\text { Indirect vertical } \\
\text { expenditure } \\
\text { externality }\end{array}$ & $\begin{array}{l}\text { Expenditure } \\
\text { interdependence }\end{array}$ & $\begin{array}{l}\text { Spending on roads } \\
\text { by cities that affect } \\
\text { fuel tax revenues }\end{array}$ & $\begin{array}{l}\text { Under provision of } \\
\text { such activities }\end{array}$ \\
\hline
\end{tabular}




\section{Horizontal tax competition}

Issues of horizontal tax competition have a long tradition in public economics. It will therefore be instructive to first briefly review what the public finance literature has to say on this type of tax competition, and then to move on to applications in the transport sector that take account of its specific characteristics (e.g., the presence of pure transit, different modes, etc.).

\subsection{Some lessons from the public finance literature}

There is a huge literature in public economics on the efficiency implications of tax exporting and tax competition, and on the resulting tax rates and levels of public service supply. First, it has been shown that tax exporting (a direct tax externality) leads jurisdictions to either tax discriminate against non-residents or to excessively tax goods that are to a large extent consumed by non-residents (see, e.g., Arnott and Grieson (1981) or Dahlby (1996)). Second, tax competition (an indirect horizontal fiscal externality) occurs whenever an increase in a jurisdiction's tax rate affects tax revenues in other jurisdictions. Jurisdictions then tend to compete for the mobile tax base. If capital is the mobile factor, many papers (e.g., Bucovetsky and Wilson (1991), Wildasin (1988); see the survey in Wilson (1999)) suggest that tax competition puts downward pressure on tax rates and yields too low a level of public good supply. Intuitively, when a country raises its tax rate it treats capital outflow as a cost, and it ignores the benefits to other regions.

Models of commodity taxation in an international setting confirm the inefficiency of tax competition. Within a general equilibrium framework, Mintz and Tulkens (1986) showed that tax rates are generally too low; this results in under provision of public services. More recently, Kanbur and Keen (1993) studied a partial equilibrium model of cross-border shopping with asymmetric regions in which the objective of regions is the maximisation of tax revenues. They showed that, at the Nash equilibrium, the small country undercuts the large country, and that the former may substantially benefit from tax competition. This is simply because of the high elasticity of tax revenues with respect to the tax rate: a low tax rate generates substantial extra revenues (see, e.g., fuel tax policy in Luxemburg). Different policy 
instruments to improve overall welfare are considered, including harmonized tax rates and the imposition of minimum tax rates. It is shown that small countries would lose by harmonisation of taxes at levels between the pre-reform taxes in the two countries. Harmonisation helps the large country if the harmonised rate is sufficiently high. A minimum tax rate between the two Nash equilibrium rates is shown to improve welfare, although this last result does not hold in more general models (Haufler (1996)).

A few recent models have considered multiple tax bases (see, e.g., Janeba and Peters (1999)) under various mobility assumptions ${ }^{1}$. They focus on the question whether preferential treatment (same tax rate on two bases) induces more or less tax competition. Finally, tax and expenditure competition have been compared in studies by, e.g., Wildasin (1989) and Upman (1998). It is found that, if public services benefit residents, the Nash equilibria in taxes and expenditures differ; moreover, expenditure competition turns out to more competitive in the sense of leading to lower levels of public spending than tax competition. If public expenditures mainly benefit industries, this last result does not generally hold.

So far, the inefficiency of tax competition has been stressed. However, recent work examines the possibilities for welfare-improving tax competition. At least three arguments have been put forward. First, competition to attract firms (through subsidies) may be efficient (Black and Hoyt (1989)) if it induces efficient firm location. Second, imperfectly competitive markets may make tax competition efficient. The seminal Brander and Spencer argument is that there will be inefficient export subsidies to domestic industries in models with Cournot competition and exogenous location. However, if firms choose location then tax competition for firms eliminates these wasteful subsidies to exports (Janeba (1998)). Third, tax competition also solves the government's commitment problems with respect to, e.g., capital investments. In the absence of tax competition, if governments determine taxes after investments have been made, there is an incentive to set taxes high. With tax competition, however, governments must keep taxes low (see, e.g., Kehoe (1989)).

\footnotetext{
${ }^{1}$ So far, little literature seems to exist on the simultaneous competition in taxes and expenditures in cases where there are benefit spillovers from expenditures (e.g., investment in infrastructure), and where tax exporting opportunities are enhanced by local spending. This may be relevant for transport markets where governments may not only compete via fuel taxes and road tolls, but they may use specific infrastructural investments as an instrument for tax exporting.
} 


\subsection{Horizontal tax competition in transport}

The lessons from the general public finance literature are extremely useful, but they are not directly applicable to transportation because of the special characteristics of the transport sector. Countries' transport networks are usually publicly provided, they are congestible, and they are accessible to local users and to transit transport ${ }^{2}$. Moreover, two prototype situations should be distinguished, where especially the second one is specific to the transport sector. This is illustrated in Figure 1

PARALLEL LINKS: transit traffic can pass via regions

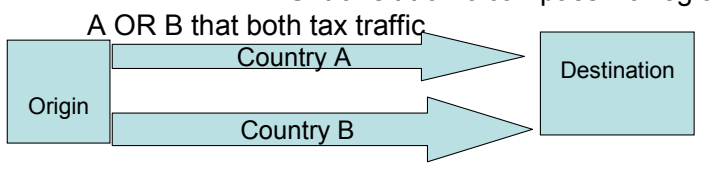

SERIAL LINKS : transit traffic passes via regions A AND

$B$ that both tax traffic

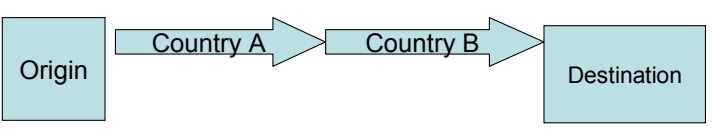

Figure 1 The two types of horizontal tax competition

One situation arises when, as is often the case, transit traffic has a choice between different jurisdictions' networks. For example, there are two main routes from South-Central Europe (Switzerland, Austria, and Italy) to the north (Belgium, Netherlands, etc.), one through France, the other via Germany. Or consider the transalpine crossing between Germany and Italy, where Austria and Switzerland compete for transit traffic. In both examples, transit has a choice of routes and it interacts with local traffic in each country. When transit has a choice of routes, where

\footnotetext{
${ }^{2}$ To avoid confusion, note that we use the term 'transit' to refer to 'through traffic', i.e., traffic that has its both origin and destination outside the country under consideration.
} 
each route is priced by a different government, we talk about (horizontal) parallel tax competition. A second type of problem arises when transit has to use a route that sequentially runs through the territory of different governments; as a consequence, the same transit traffic can be taxed by each of the governments. Obvious examples are trucks running from Spain to the Netherlands; they can, among others, be tolled in France and in Belgium. Other examples of competition can occur at the level of transfer facilities that are owned by different governments. Obviously, these issues are extremely relevant in view of Trans European Networks (TEN's) discussed within the EU. We denote these issues as (horizontal) serial tax competition. The main difference with parallel tax competition is that transit has no route choice anymore, the only choice is to forego the trip.

\subsubsection{Parallel tax competition}

What can we learn from the scarce literature on parallel tax competition in transport? The public finance literature suggests that inefficiencies will result due to competition for revenues and tax exporting behaviour; these suggestions have to be revaluated in the presence of externalities and the specific context of transport markets. We first review some relevant findings from the literature and then illustrate some important implications on the basis of one specific simple model.

Although not specifically dealing with tax competition, it is useful to start our review by looking at some preliminary results. First, the problem of one government responsible for optimally taxing a parallel network has been explored in great detail in the literature. If road users are homogenous, the results show that there are important welfare losses when for some reason not all links can be optimally tolled (e.g., Braid (1996) and Liu and McDonald (1998)). However, more recent research by Small and Yan (2001) and Verhoef and Small (2004) shows that allowing for a heterogeneous population of road users substantially increases the benefits from second best tolls. Second, relevant information can also be obtained from the growing literature that explicitly studies the role of different ownership regimes in models with parallel routes. For example, Verhoef et al. (1996) consider competition between a private 
road and a free-access road, and compare the second-best optimal tolls with those obtained when both roads are privately owned. De Palma and Lindsey (2000) use a bottleneck model of congestion and compare three types of ownership structure: a private road competing with a free access road, two competing private roads, and competition between a private and a public operator.

The above papers do not distinguish between transit and local traffic demand and, therefore, do not specifically deal with tax competition for transit by welfare maximising governments. In fact, only a few models explicitly look at horizontal tax competition between governments in two-region models with transport externalities. Bjorner (1996) looks at first-best outcomes in a simple two product-two country general equilibrium model, where production of one good uses freight transport (both on domestic and foreign territory) as an input apart from labour, and illustrates the potential for tax competition and tax exporting. More recently, De Borger, Courcelle and Swysen (2004) apply a large-scale numerical optimisation model to study tax policies by individual regions in a model with both domestic and international freight transport. The empirical analysis mainly illustrates tax exporting behaviour of individual countries: optimal tax rates rise when transit shares increase. The welfare losses from strategic pricing by individual regions are found to be relatively small.

To understand some important implications of tax competition between governments on parallel road networks, the most instructive way is probably to use a very simple intuitive model. In the remainder of this subsection, we therefore illustrate some useful results derived in De Borger, Proost and Van Dender (2004). The model has two parallel routes that are operated by two countries, for given levels of infrastructure supply. Both local and transit traffic contribute to congestion, and the two countries compete for revenue from transit. Assuming that countries maximise a welfare function consisting of local consumer surplus and tax revenues from local and transit traffic, the paper studies strategic tolling by individual countries under various tolling schemes. Three types of tolling are studied, as described in Table 2 .

Despite a number of obvious simplifications, each of the three tolling regimes has policy-relevant applications within the EU. Among others, the case of differentiated tolls is relevant because, when EU member states use different tolling instruments for local and transit transport, the implied tax levels will automatically 
differ. The case of uniform tolls provides an appropriate description when EU member countries use the same pricing instruments, because explicit toll discrimination between local and transit transport contradicts EU regulations. Finally, the case of 'local tolls only' is not unlike the current situation in many countries, where fuel taxes are the main tolling instrument that can easily be evaded by transit transport by fueling elsewhere.

Table 2: Different types of tolling and parallel tax competition

\begin{tabular}{|l|l|}
\hline $\begin{array}{l}\text { TYPE } \\
\text { TOLLING }\end{array}$ & DESCRIPTION \\
\hline Toll discrimination & Home users are tolled differently than transit users \\
\hline Uniform toll & Home users and transit users pay the same toll \\
\hline Local traffic only & Only home users can be tolled \\
\hline
\end{tabular}

The major theoretical insights from the model can be summarised as follows. First, if countries can charge differentiated tolls to home users and transit users, they will typically set the transit toll strictly larger than the local toll. This simply reflects tax exporting behaviour (see, e.g., Arnott and Grieson (1981), Wilson (1999)). Importantly, however, it is shown that both the local toll and the toll on transit exceed the local marginal external cost. This is due to the interaction of local and transit demand in generating congestion. The local tax should reflect the true opportunity cost of an increase in local traffic; however, this not only covers the local direct marginal external cost, but also the opportunity cost of the lost tax revenues on transit. Indeed, more local traffic implies higher congestion and hence less transit demand. As a consequence, the toll on home users exceeds the marginal congestion cost.

Second, it is found that if countries are restricted to use uniform tolls, then the optimal uniform toll exceeds the local direct marginal external cost; moreover, it rises with transit. Again, except for the role of congestion, this is in line with the earlier tax competition literature. Intuitively, the toll balances the distortion on the local transport market and the revenue opportunities from transit. If transit captures a large share of all traffic in a country, this will be reflected in a higher uniform toll. 
Third, if a government can only toll local users, then it is shown that it should optimally select tolls that are lower than the local direct marginal cost (the negative externality imposed upon the local users). To understand why this is the case, note that the toll reduces local transport demand. However, this in turn reduces the marginal private time cost for transit and attracts more transit, decreasing local welfare. The consequence is that it is best to charge a tax below the local marginal external cost. In fact, if transit traffic reacts very strongly to an average travel time cost decrease, it may be optimal to set the tax very low so as to avoid attracting too much transit.

In order to check whether these theoretical predictions are confirmed, and to find out how important the inefficiencies of parallel tax competition are, one procedure is to use numerical simulations. Table 3 summarizes the results of one particular simulation with two parallel and identical roads. The table compares a situation with zero tolls with various Nash equilibria and with a centrally optimal solution in which all fiscal externalities are internalized. Note that, in the absence of tolling, it was assumed that transit represented $50 \%$ of total transport flows. Looking at the results, note that in the Nash equilibrium with differentiated tolls, both the local and transit toll exceed the local marginal external cost, the local toll is equal to the global marginal external congestion cost, and the transit toll exceeds the local toll. This contrasts to the centralised solution, where both transit and local tolls equal the global marginal external cost. In the Nash equilibrium with uniform tolls, the optimal toll is between the toll levels of the differentiated case. Interestingly, the optimal local toll is very low in the Nash equilibrium case where transit remains un-tolled: it amounts to 6.8 Euro relative to a global marginal external cost of 30.7 Euro.

Concerning the relative welfare levels at the different equilibria, three types of results follow from the final row in the table. First, it tells us that the Nash equilibrium with differentiated tolls is able to generate a large percentage $(93 \%)$ of the maximal possible welfare gain at the centralised solution. This suggests that the welfare costs of the lack of coordination between countries are relatively modest ${ }^{3}$. Importantly, it shows that tolling with no coordination is much better than no tolling at all. Second, when we compare the Nash equilibrium with and without toll differentiation, the

\footnotetext{
${ }^{3}$ This result is in line with the few explicit numerical illustrations of the welfare effects of various types of tax competition. An early example is Wildasin (1989), who finds substantial welfare effects of property tax competition in the US. More recently, Sorensen (2000) estimates the welfare gain of tax harmonisation within the EU at less than $1 \%$ of GDP.
} 
uniformity constraint implies a very small overall welfare loss, despite a substantial impact on the local toll. Local welfare goes down only marginally because the reduction in local consumer surplus is almost fully offset by the increase in tax revenues. The results indicate that the overall welfare effects of uniform versus differentiated tolls are quite similar, although the distribution between local and transit welfare, and the composition of local welfare are substantially different. Third, if transit cannot be tolled, we find the performance of both the Nash and the centralised outcome to be substantially worse than in the cases where transit is indeed tolled.

Table 3 Illustration of parallel tax competition

\begin{tabular}{|l|c|c|c|c|c|c|}
\hline & $\begin{array}{c}\text { No } \\
\text { tolls }\end{array}$ & $\begin{array}{c}\mathrm{NE}- \\
\text { diff. }\end{array}$ & $\begin{array}{c}\mathrm{NE}- \\
\text { unif. }\end{array}$ & $\begin{array}{c}\text { NE- } \\
\text { local }\end{array}$ & $\begin{array}{c}\text { Centr. }- \\
\text { diff. }\end{array}$ & $\begin{array}{c}\text { Centr. - } \\
\text { local }\end{array}$ \\
\hline Local toll (Euro/trip) & 0 & 27.1 & 36.8 & 6.8 & 27.7 & 27.5 \\
\hline Transit toll (Euro/trip) & 0 & 37.9 & 36.8 & 0 & 27.7 & 0 \\
\hline Local MEC (Euro/trip) & 15.6 & 13.9 & 13.3 & 15.1 & 13.8 & 13.7 \\
\hline Global MEC (Euro/trip) & 31.1 & 27.1 & 26.5 & 30.7 & 27.7 & 29.4 \\
\hline Share max. W gain (\%) & 0 & 93 & 89 & 22 & 100 & 49 \\
\hline
\end{tabular}

(Source: De Borger et al.(2004))

\subsubsection{Serial tax competition}

Serial tax competition may be highly relevant in the transport world in Europe and the US. Many interstate highways or railroads in the US, and the EU's Trans European Networks potentially face this problem. Different countries may apply individual tolling instruments on their part of the network, with potentially substantial welfare losses as a result. Moreover, serial tax competition also arises with multimodal transfers in both passenger and freight transport when each mode is operated by a different authority.

Despite its importance, serial tax competition in transport has not been widely researched. In fact, the implications of tax competition for tax rates under different 
tolling regimes and the associated welfare effects have not been studied in detail at all. One important reference on serial horizontal tax competition in transport is Levinson (2001). He analyses US States' choice of instruments for financing transportation infrastructure. Theory predicts, and an econometric analysis confirms, that jurisdictions are more likely to opt for toll-financing (instead of, e.g., fuel taxes) when the share of non-residential users is large. Obviously, tolls become more attractive because they allow price discrimination and tax-exporting. More recently, Verhoef and Rouwendal (2003) consider a simple network model that has a simple serial structure as a special case, and they look at the interrelation between pricing, capacity choice and financing of infrastructure. However, neither of the above models fully investigates optimal tax structures under tax competition, nor looks in details at their welfare effects.

Making abstraction of externality issues, the serial tax competition problem bears some analogies to the problem of vertical integration in the literature on industrial organisation (see, e.g., Tirole (1988)); these may be usefully exploited in future research. One can show that, when there is monopolistic behaviour both on the output market and on the market for intermediate inputs, every producer applies his optimal profit margin without realising that he decreases the profit base of the other producers in the supply chain. The result is 'double marginalisation': overall markups are higher but total profits lower than in the case with full vertical integration. As Tirole (1988) puts it : "What is worse than a monopoly? A chain of monopolies".

When we transpose these ideas to a serial network, the potential for excessive overall taxation of inter-country or inter-modal trips is clear, at least to the extent that different authorities are involved in setting taxes on the different stretches of the serial network. To see the intuition, it is useful to hypothetically start from the extreme case with zero local transport. If there is only transit traffic, then individual countries or regional authorities will charge fees well in excess of the marginal external cost; overall trip tolls will be much larger than the welfare optimising sum of individual tolls. In welfare terms, serial toll competition may be drastically worse compared to a fully integrated serial network operated by one welfare maximising authority. When there is also local transport, the analogy is less straightforward but serial competition is not necessarily beneficial in welfare terms (De Borger, Proost and Van Dender, forthcoming 2004). 


\section{Vertical tax competition}

Again, we start by briefly reviewing the lessons from the public finance literature before moving on to the applicability in the transport sector.

\subsection{Lessons from public finance theory}

Vertical tax competition (an indirect fiscal externality) between a higher and lower level of government may result if tax policies of one level of government affect tax revenues at another level due to, e.g., sharing of tax bases. The associated inefficiencies depend on whether governments are benevolent or not (welfare maximising or revenue maximising), on whether the game is Nash or Stackelbergh, and on the existence of limits on the available tax instruments. First, assume benevolent governments and suppose the federal government is interested in 'correcting' vertical inefficiencies at lower levels (i.e., it is the leader in a Stackelbergh game; see, Boadway and Keen (1996) and Boadway et al (1998)). The typical argument then is that the lower level sets tax rates inefficiently high because it ignores the effect of its taxation on the tax revenues for the higher level government. One shows that the federal level can in principle undo any vertical inefficiency created by the lower level of government by combinations of taxes-subsidies and intergovernmental grants.

Second, if benevolent federal and local governments move simultaneously (Nash game), Hoyt's (2001) model with identical local governments implies that the federal level cannot affect tax policies of local governments, but through its own choice of tax rate on the overlapping tax base it can still induce the efficient overall tax rates. Grants are then used to obtain the appropriate mix of local and federal public services. These results do not hold in a system of regions where each local authority chooses its own tax rate such as the EU. In that case the higher level cannot restore efficiency by setting the federal tax rates, which are uniform across regions. Moreover, if the federal level cannot use grants, it will lower its tax rates to partially offset the fiscal externality and reduce federal public good provision. If in addition tax bases do not fully overlap in the sense that the federal level has additional 
instruments, it should actually subsidize some goods that are inefficiently taxed by lower level governments.

Third, if governments are not benevolent the results drastically change. For example, if governments maximise revenues instead of welfare (Keen and Kotsogiannis (2003)) a reduction of tax rates from the Nash equilibrium levels is welfare-improving and raises total tax revenues (i.e., bringing countries on the wrong side of the Laffer curve).

\subsection{Vertical tax competition in the transport economics literature}

Despite its relevance for the transport sector, the insights of the public finance literature on vertical tax competition have hardly been translated or applied to transport taxation and pricing. That the issue is important is clear. Most transport flows are not only taxed or subsidised in various different ways, but typically the different taxes are set by different hierarchical levels of government. For example, people that both use their private car and public transport face payments of registration taxes on their cars, they pay fuel taxes, they pay public transport fares, they may face road tolls, etc. Some of the taxes may be set by higher level governments (e.g., in most countries fuel taxes are determined at the national level), but public transport fares and road tolls may be set by local authorities. Moreover, in some cases clear rules exist for the sharing of the revenues generated out of the various taxes.

The literature discussed in section 4.1 shows that this type of problem has been studied in the public finance literature, but it has not been applied systematically to transport pricing. In fact, theoretical and empirical optimal transport pricing models with higher and lower level governments that imply vertical tax externalities is extremely scarce. De Borger et al. (1998) and Proost and Sen (2003) contain very preliminary illustrative analyses of the problem. The former paper illustrates different pricing optima for a city government (Brussels) and a regional government within a country (Belgium) and considers simple forms of revenue-sharing, but it does not formally analyse the optimal policies that correct the vertical inefficiencies. The latter study first theoretically illustrates the optimal tax problem when a local and a national 
government are involved in a Stackelbergh game, and it empirically verifies some of the theoretical predictions.

In what follows we limit the discussion to, first, an intuitive explanation of the nature and the importance of the problem and, second, a brief review of a specific case study that helps to illustrate the potential implications of this type of competition.

\subsubsection{Identification of the problem}

The vertical tax problem arises because different levels of government may be responsible for different transport policy instruments; this induces a number of complicated interactions because of overlap of tax bases, differences in objectives between governments, spill-overs of externalities, etc. As an example, suppose that in a given country the national level is responsible for a number of policy instruments such as setting fuel taxes, road pricing, etc. Within the country, however, city governments may be responsible for local congestion charges, local public transport prices, parking fees, etc. These instruments can be used to correct local congestion in the urban area. Moreover, note that each government is likely to have different objectives, and it probably takes different external costs into account. For example, the urban government may only care about externalities imposed on the local population, and its interpretation of 'welfare' may be largely limited to the concern for the urban population; only to a minor extent does it care about non-urban residents such as commuters. Table 4 summarizes the most relevant information on the characteristics of the overall problem just described. 
Table 4: Local and global optima with vertical interaction

\begin{tabular}{|l|l|l|}
\hline Externality spillover & $\begin{array}{l}\text { Cares about externalities } \\
\text { imposed on city residents } \\
\text { only; e.g. ignore time } \\
\text { losses for commuters }\end{array}$ & $\begin{array}{l}\text { Cares about externalities } \\
\text { imposed on all national } \\
\text { residents; e.g. internalise } \\
\text { commuting time losses }\end{array}$ \\
\hline Tax exporting & $\begin{array}{l}\text { Yes; export taxes to non- } \\
\text { residents }\end{array}$ & No \\
\hline $\begin{array}{l}\text { Overlapping tax bases: } \\
\text { indirect vertical fiscal } \\
\text { externality }\end{array}$ & Partially & Partially \\
\hline $\begin{array}{l}\text { Differences in tax } \\
\text { instruments }\end{array}$ & $\begin{array}{l}\text { Use of local congestion } \\
\text { taxes, local public } \\
\text { transport prices, parking } \\
\text { fees }\end{array}$ & $\begin{array}{l}\text { Use of all instruments, } \\
\text { including fuel taxes }\end{array}$ \\
\hline Tax revenue & $\begin{array}{l}\text { Local congestion taxes, } \\
\text { local public transport } \\
\text { surplus or deficit, parking } \\
\text { fees }\end{array}$ & $\begin{array}{l}\text { Fuel taxes, all congestion } \\
\text { taxes, all non-local public } \\
\text { transport net revenues }\end{array}$ \\
\hline Shadow cost of funds & Local & National \\
\hline
\end{tabular}

The above concrete problem setting allows us to easily identify at least four reasons why the tax structure and the level of taxation will be suboptimal:

(i) There are fiscal externalities associated with overlapping tax bases. An increase in federal fuel taxes reduces transport demand, including local transport, and therefore affects the local congestion toll revenues and public transport revenues for the city government. This is ignored by the national government in setting fuel taxes, yielding too high federal taxes. From the vieuwpoint of the city government, a federal fuel tax increase is treated as an increase in resource cost.

(ii) Tax exporting by the city government. This is due to the fact that the city government cares less about commuters than about city residents. The implication is that local congestion charges on commuters will be excessively high from an overall welfare viewpoint.

(iii) There are externality spillovers. The local authorities only care about externalities imposed on local residents; this induces them to set local taxes too low. 
(iv) The use of imperfect and different instruments by different governments. The local government only controls a local congestion tax and local public transport prices to correct externalities.

\subsubsection{Some intuition based on a simple example}

The interaction of all the above implications of vertical tax competition leads to results that are difficult to fully predict a priori. We therefore illustrate the consequences for tax levels and welfare using a simple numerical example described in Proost and Sen (2003). They consider the case where only two policy instruments are available: the only instrument under control of an urban government are local parking fees, and an (overlapping) regional government decides on a peak period cordon toll around the area to control congestion. The cordon toll is paid only by commuters, not by local city residents. The role of each government level is defined in table 5 .

Note that the two levels of governments are supposed to receive the full revenues of the tax instruments they control. Moreover, we assume that the behaviour of each government level consists of maximising the welfare of the representative citizen in its constituency: the urban government maximises the welfare of its inhabitants only, whereas the regional government maximises the sum of the welfare of all citizens (i.e., its urban citizens and its commuters, where the weights correspond to their relative importance in the population). 
Table 5 Structure of the policy game

\begin{tabular}{|c|c|c|}
\hline & URBAN GOVERNMENT & $\begin{array}{l}\text { REGIONAL } \\
\text { GOVERNMENT }\end{array}$ \\
\hline Instruments controlled & Parking fee for all cars & $\begin{array}{l}\text { Level of cordon toll } \\
\text { (uniform over time) }\end{array}$ \\
\hline Share in parking revenues & $\begin{array}{l}100 \% \text { of parking fee } \\
\text { revenue (in excess of } \\
\text { resource cost) is } \\
\text { redistributed to urban } \\
\text { citizens }\end{array}$ & 0 \\
\hline $\begin{array}{l}\text { Share in cordon toll } \\
\text { revenues }\end{array}$ & 0 & $\begin{array}{l}100 \% \text { of cordon toll } \\
\text { revenue is redistributed to } \\
\text { commuters }\end{array}$ \\
\hline Welfare function & $\begin{array}{l}\text { Welfare of representative } \\
\text { urban citizen }{ }^{4}\end{array}$ & $\begin{array}{l}\text { Welfare of representative } \\
\text { urban citizen and of } \\
\text { representative commuter }\end{array}$ \\
\hline
\end{tabular}

The main research questions are: first, how do parking fees and congestion charges differ between centralised and decentralised solutions? Second, what is the welfare loss we can expect from non coordinated policies? Third, what determines these welfare losses? To study these questions, three alternative equilibria for the policy game between the two governments are considered: (i) a centralised outcome where all decisions (parking fees, cordon charges) are taken by the regional government, (ii) the Nash equilibrium solution, and (iii) a Stackelberg equilibrium where it is assumed that the regional government announces its cordon pricing policy first. A Stackelberg equilibrium where the regional government is the leader is more credible than the reverse (in which the urban government would first announce its parking policy) because the regional government may very well need to announce a harmonised policy guideline for several urban areas at the same time.

The results are summarized in Table 6. First consider the centralized equilibrium. The best equilibrium one can achieve is an equilibrium with parking fees (expressed per passenger kilometer) of 0.246 and 0.101 for residents and commuters, respectively, and a cordon toll on commuters of 0.301 . Parking fees increase above

\footnotetext{
${ }^{4}$ The external costs (air pollution, noise, accidents) borne by the urban government are proportional to the share of its citizens in the total (inhabitants plus commuters) population.
}

Formatted: Heading 3; Heading 31; Heading 32; Heading 33; Heading 34; Heading 35; Heading 36; Heading 311; Heading 321; Heading 331; Heading 341; Heading 351 ; Heading 37; Heading 312; Heading 322; Heading 332; Heading 342; Heading 352; Heading 313; Heading 323; Heading 333, Line spacing: single 
the resource costs because the cordon toll only affects the peak car demand of the commuters. This combination of optimal parking and cordon tolls achieves a welfare gain of $1.55 \%$ compared to the reference situation,

Deleted: ๆ

Table 6 Performance of the different equilibria

\begin{tabular}{|c|c|c|c|c|}
\hline & $\begin{array}{l}\text { Regional } \\
\text { Welfare }\end{array}$ & $\begin{array}{l}\text { optimal } \\
\text { parking }\end{array}$ & $\begin{array}{l}\text { optimal } \\
\text { cordon toll }\end{array}$ & $\begin{array}{l}\text { \% regional } \\
\text { welfare } \\
\text { Gain } \\
\end{array}$ \\
\hline & & IN OUT & & \\
\hline Centralised Solution & 55.221 & 0.2460 .10 & 0.301 & 1.55 \\
\hline Nash Solution & 55.13 & $0.27 \quad 0.11$ & 0.29 & 1.38 \\
\hline Stackelberg Solution & 55.16 & $0.22 \quad 0.09$ & 0.44 & 1.43 \\
\hline Ref. Eq.(reference Parking) & 54.38 & & & 0 \\
\hline
\end{tabular}

Note: IN - Insiders of urban area; OUT- Outsiders or commuters 
To understand the non-cooperative outcomes (Nash-Stackelbergh) it is useful to realize that in our model setting one expects the urban government to try to tax commuters via high parking fees, because this revenue is redistributed to the urban citizens only. Parking fees therefore act as a potential tax exporting mechanism. On the other hand, however, the regional government is interested in relatively high cordon tolls to reduce congestion and to generate revenues. To understand the interactions, consider Figure 1; this depicts the reactions functions of the two governments. The flatter reaction function is the reaction function of the urban government that chooses its preferred parking fee for a given cordon toll. The steeper reaction function represents the optimal cordon toll chosen by the regional government for a given parking fee. The centralized solution is obviously a point on this latter reaction function, the Stackelbergh outcome is on the urban govenrment's reaction function. The Nash equilibrium is obviously the intersection of the two curves.

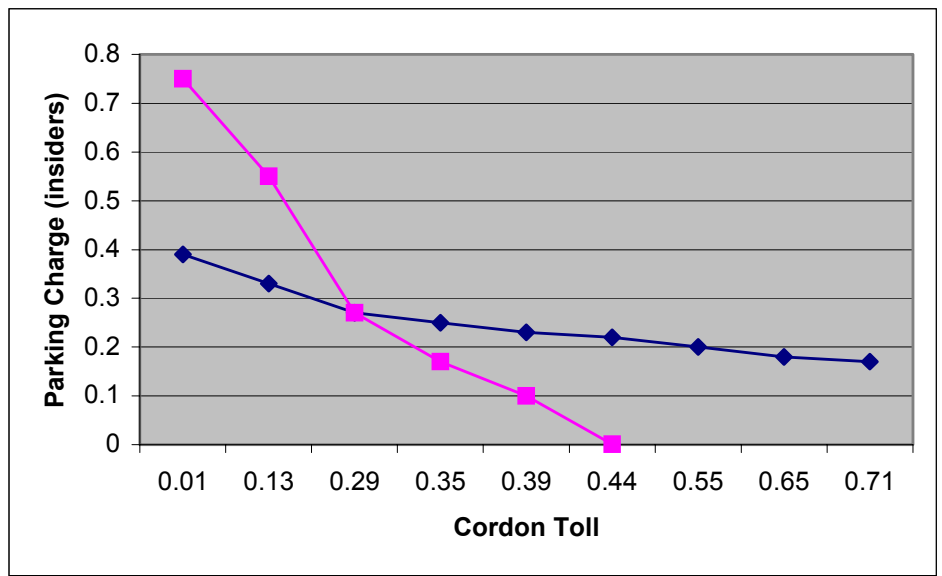

Figure 1: Reaction functions of urban and regional government

With these considerations in mind let us turn to the non-cooperative outcomes. It follows from Table 6 that the Nash outcome, compared to the centralized solution, has higher parking fees (0.27 for residents) and a lower cordon toll (0.29). Surprisingly, note that the degree of tax exporting through high parking charges on commuters is quite limited, mainly due to the regional government's high cordon toll. Another striking result is that the welfare gain achieved by the non-coordinated solution is only some $10 \%$ lower than the fully coordinated solution. To some extent, 
this is due to the choice of instruments and the allocation of responsibilities. For example, the outcomes would have been quite different if the cordon toll was controlled by the urban government: this would lead to very high tolls on commuters and probably much larger inefficiencies.

Looking at the Stackelberg solution, note that the regional government takes into account the tendency of the urban government to charge too high parking fees and announces therefore a relatively high cordon toll (0.44 rather than 0.29$)$. Given this high toll, the urban government limits its parking fees (0.22 rather than 0.27). Because the regional government has the same welfare function as the centralised solution we can achieve a better overall welfare level than in the Nash equilibrium. Compared to the centralised solution, one achieves a welfare level that is $7.75 \%$ lower.

Finally, the effects of different rules for sharing the revenues were considered. In the case reported in Table 6, it was assumed that the urban government did not receive any share in the cordon toll revenue. The consequence was an urban government that used the parking fee to extract revenue from commuters. One way to give a more balanced incentive for the urban government is to give it also a share in the cordon toll revenues. Allocating a fixed share (equal to half its share in total population- inhabitants plus commuters) of the cordon toll revenues to the urban government was found to lead to a Nash equilibrium that is more efficient. It yielded lower parking charges and a higher toll, and a loss compared to welfare in the centralised case of only $6.5 \%$ instead of $10 \%$. Also the Stackelberg solution does better: it performs now only $3 \%$ less efficient than the centralised solution. In other words, sharing the revenues can lead to more efficient equilibria with higher overall welfare levels. The price to pay for this higher efficiency is a less equitable distribution of welfare as the commuters receive now an even smaller share of the tax revenue they pay.

Despite the extremely simple setting used for this example, there are some useful lessons to be learned. We offer three tentative conclusions:

1. Very often pricing instruments are chosen by different overlapping government levels. Even if they each maximise the welfare of all their voters, this generates inefficiencies because of overlapping tax bases and a tendency for tax exporting by the core urban area. 
2. Non-cooperative equilibria do not necessarily perform very poorly in welfare terms as long as each government cares about externalities. In a sense, correcting externalities is more important than the side effects of tax competition. We found the Nash and Stackelberg equilibrium were only $5 \%$ to $10 \%$ less efficient than the fully coordinated centralised solution.

3. Changing the sharing rules for tax revenue can decrease the welfare loss of noncooperative equilibria.

\section{Suggestions for further research}

In this paper we surveyed the literature on horizontal and vertical tax competition in the transport sector. In this concluding section we indicate some important topics for future research.

Consider parallel horizontal tax competition. What are the main challenges? A first one is to focus on more detailed and realistic pricing instruments. The existing theoretical literature implicitly looks at kilometre charges, but the precise distinction between fuel taxes, road tolls, cordon pricing, etc. has not convincingly been made. Second, it is important to incorporate other instruments apart from pricing. Specifically, there is a need to introduce investment as a strategic instrument. Not only is capacity a strategic factor in tax revenue generation, but it also directly affects congestion. Given the difficulties in solving joint pricing-capacity problems, this extension may be difficult (see, e.g., Kraus (2003), Verhoef and Rouwendal (2003)), but the insights gained will be very useful. Third, introducing capacity also raises the issue of optimal instrument choice by a central (for example, at the EU level) government coordinating horizontal competition. Fourth, it seems desirable to carefully study under what condition there exist possibilities for welfare-improving tax competition. The public finance literature has produced a substantial literature on beneficial tax competition in a dynamic context (Kehoe (1989), Janeba (1998)). The question is whether such beneficial tax competition matters in a transport setting. As yet, no research along these lines has been produced. Finally, there is a need for more empirical studies on the welfare effects of tax competition using realistic and real world information on existing networks. Currently available studies by and large limit 
applied work to simple illustrative numerical examples. It remains to be seen whether the costs of non-cooperative behaviour are substantial or not.

As far as serial horizontal tax competition is concerned, it seems that this area is largely underdeveloped. First, given its importance in view of the EU's Trans European Networks and intermodal transport flows, theoretical research on the implications of this type of competition is highly needed. Probably a lot can be learnt from double marginalisation results in vertical integration theory in industrial organisation, but specific transport characteristics may imply important additional features. Moreover, here as well, the possibilities for welfare-improving tax competition have to be addressed. Second, here as well there is a need to not just consider pricing instruments, but also incorporate investment. Governments will indeed use capacity as a strategic instrument in a serial setting. Third, optimal instrument choice by a coordinating central government is again relevant. Realistic applications with real data are needed to evaluate the welfare effects.

Concerning vertical tax competition, it is necessary to provide more theoretical insights on the results of vertical tax interaction with realistic pricing instruments (which government controls which instruments, optimal allocation of authority, etc.) and reasonable tax sharing rules. Moreover, the mechanisms available to correct inefficiencies, including various revenue sharing instruments, should be studied in detail. Again, numerical analysis using real world cases is highly desirable to appreciate the welfare effects of non-coordination.

Finally, more research on the political economy of using price and regulatory instruments is necessary. How do countries decide on their tax and toll instruments? Case study approaches (London, kilometre charges in Germany, etc.) may be useful here. Which instruments and levels are more likely to be observed? Why, despite substantial support from economists, are tolling instruments not frequently used? More work is needed here. 


\section{REFERENCES}

Arnott, R. and R. Grieson (1981), Optimal fiscal policy for a state and local government, Journal of Urban Economics 9, 23-48.

Bjorner (1996), Any need for coordination of policies towards transit traffic with a negative local externality? Environmental and Resource Economics 8, 221.245 .

Black, D. and W. Hoyt (1989), Bidding for firms, American Economic Review 79, 1249-1256.

Boadway, R., Marchand, M and M. Vigneault (1998), The consequences of overlapping tax bases for redistribution and public spending in a federation, Journal of Public Economics 68, 453-478.

Braid, R. (1996), Peak-load pricing of a transportation route with an unpriced substitute, Journal of Urban Economics 40, 179-197.

Bucovetsky (1991), Asymmetric tax competition, Journal of Urban Economics 30 , 167-181.

Dahlby, B. (1996), Fiscal externalities and the design of intergovernmental grants, International Tax and Public Finance 3, 397-412.

De Borger, B and S. Proost, Eds. (2001), Reforming transport pricing in the European Union, Edward Elgar, Cheltenham, UK.

De Borger B., Proost S. and K. Van Dender (2004), Congestion and tax competition on a parallel network, discussion paper 2004-003, University of Antwerp.

De Borger B., Proost S. and K. Van Dender (2004), The serial tax competition problem in transport networks, forthcoming.

De Borger, B., Courcelle, C. and D. Swysen (2004), Optimal pricing of transport externalities in an international environment: empirical evidence based on a numerical optimisation model, Regional Science and Urban Economics 34, 163-201.

De Borger, B., Ochelen, S., Proost, S. and D. Swysen (1998), Regional and federal interests in transport and environment policy-making: the case of Belgium, in S. Proost and J. Braden, Climate change, Transport and Environmental policy, Edgar Elgar, 221-243.

de Palma, A. and R. Lindsey (2000), Private toll roads: a dynamic equilibrium analysis, Annals of Regional Science, 34, 1, 13-35 
Dixit A., G.M.Grossman, E.Helpman, (1997), "Common agency and coordination: general theory and application to government policy making”, JPE, vol 105, $\mathrm{N}^{\circ} 4$, p 752-769

Haufler, A. (1996), Optimal factor and commodity taxation in a small open economy, International Tax and Public Finance 3(3), 425-442.

Hoyt, W. (2001), Tax Policy coordination, vertical externalities and optimal taxation in a system of hierarchical governments, Journal of Urban Economics 50, 491-516.

Janeba, E. (1998), Tax competition in imperfectly competitive markets, Journal of International Economics 44, 135-153.

Janeba, E. and W. Peters (1999), Tax evasion, tax competition and the gains from nondiscrimination: the case of interest taxation in Europe, Economic Journal 109, 93-101.

Kanbur, A. and M. Keen (1993), Jeux sans frontières: tax competition when countries differ in size, American Economic Review 83, 877-892.

Keen, M. (1998), Vertical tax externalities in the theory of fiscal federalism, International Monetary Fund Staff Papers 45, 454-484.

Keen, M. and C. Kotsagiannis (2003), Leviathan and capital tax competition in a federation, Journal of Public Economic Theory 5, 177-199.

Kehoe, P. (1989), Policy coordination among benevolent governments may be undesirable, Review of Economic Studies 56, 289-296.

Kraus, M. (2003), A new look at the two-mode problem, Journal of Urban Economics $54,511-530$.

Levinson, D. (2001), Why States Toll - An empirical model of finance choice, Journal of Transport Economics and Policy, 35, 2, 223-238

Liu, L. and J.F. McDonald (1998), Efficient congestion tolls in the presence of unpriced congestion: a peak and off-peak simulation model, Journal of Urban Economics 44, 352-366.

Mintz, J. and H. Tulkens (1986), Commodity taxation between member states of a federation: equilibrium and efficiency, Journal of Public Economics 29, 173197.

Proost, S. and A. Sen (2003), Implementation of pricing policies with two government levels, Center for Economic Studies, Catholic University Leuven, Discussion Paper ETE . 
Small, K. and J. Yan (2001), The value of "Value Pricing" of roads: second best pricing and product differentiation, Journal of Urban Economics, 49, 2, 310336

Sorensen, P. (2000), Tax coordination: its desirability and redistributional implications, Economic Policy 15, 431-472.

Tirole J. (1988), The Theory of Industrial Organisation, MIT press

Upman, T.B. (1998), Two games of interjurisdictional competition when local governments provide industrial public goods, International Tax and Public Finance 5, 471-488.

Verhoef, E. and J. Rouwendal (2003), Pricing, capacity choice and financing in transportation networks, Tinbergen Institute Discussion Paper TI2003-027/3.

Verhoef, E. and K. Small (2004), Product differentiation on roads: second-best congestion pricing with heterogeneity under public and private ownership, Journal of Transport Economics and Policy 38, 127-156.

Verhoef, E., P. Nijkamp and P. Rietveld (1996), Second-best congestion pricing: the case of an untolled alternative, Journal of Urban Economics 40, 279-302.

Wildasin, D. (1989), Interjurisdictional capital mobility: fiscal externality and a corrective subsidy, Journal of Urban Economics 25, 193-213.

Wildasin, D. (1988), Nash equilibria in models of fiscal competition, Journal of Public Economics 35, 229-240.

Wilson, J. (1999), Theories of tax competition, National Tax Journal 52, 269-304. 
The Center for Economic Studies (CES) is the research division of the Department of Economics of the Katholieke Universiteit Leuven. The CES research department employs some 100 people. The division Energy, Transport \& Environment (ETE) currently consists of about 15 full time researchers. The general aim of ETE is to apply state of the art economic theory to current policy issues at the Flemish, Belgian and European level. An important asset of ETE is its extensive portfolio of numerical partial and general equilibrium models for the assessment of transport, energy and environmental policies.

\section{ETE WORKING PAPER SERIES 2004}

N²004-12

N²004-11

N²004-10

N²004-09

$N^{\circ} 2004-08$

N²004-07

N²004-06

$n^{\circ} 2004-05$

$n^{\circ} 2004-04$

n²004-03

$n^{\circ} 2004-02$

n²004-01
De Borger B., Proost S. (2004), Vertical and horizontal tax competition in the transport sector

de Palma A., Dunkerley F., Proost S. (2004), Imperfect Competition and Congestion in a City with asymmetric subcenters

Calthrop E., Proost S. (2004), Regulating on-street parking

de Palma A., Proost S. (2004) Imperfect competition and congestion in the City

Pepermans G., Willems B. (2004), Ramsey Pricing in a Congested Network with Market Power in Generation: A Numerical Illustration for Belgium

Delhaye E. (2004), Traffic safety: speed limits, strict liability and a km tax

Eyckmans J., Finus M. (2004), An Empirical Assessment of Measures to Enhance the Success of Global Climate Treaties

Eyckmans J., Meynaerts E., Ochelen S. (2004), The Environmental Costing Model: a tool for more efficient environmental policymaking in Flanders

Saveyn B., Proost S. (2004), Environmental Tax Reform with Vertical Tax Externalities in a Federal State

Rousseau S. (2004), Timing of environmental inspections: Survival of the compliant

Knockaert J., Proost S., Van Regemorter D. (2004), Analysis of transport policy scenarios for EU-countries with PRIMEStransport

Franckx L., de Vries F.P. (2004), Environmental Liability and Organizational Structure

\section{ETE WORKING PAPER SERIES 2003}

